\title{
Market Conditions and the Exit Rate of Private Equity Investments in an Emerging Economy
}

Andréa Maria Accioly Fonseca Minardi ${ }^{1}$ Adriana Bruscato Bortoluzzo ${ }^{1}$ Piero Rosatelli ${ }^{1}$

Priscila Fernandes Ribeiro ${ }^{1}$

Insper, São Paulo, SP, Brazil ${ }^{1}$

Received 13 June 2018. This paper was with the authors for three revisions. Accepted 22 May 2019. First published online 19 July 2019.

Kelmara Mendes Vieira was the associate editor for this article.

Editorial assistant: Luciane Kato Kiwara

Editor-in-chief: Carlo Gabriel Porto Bellini 


\begin{abstract}
Private Equity (PE) funds are active investors. Besides providing capital, they improve the governance, operational performance and innovation of the investee companies. However, potential misalignment between the fund manager and the company owner regarding exit timing is a limitation of the model. PE funds have a finite-life, and thus they have to liquidate investments after holding them for a certain period. They tend to time the market to exploit favorable market conditions and obtain higher selling prices, and consequently, PE funds may divest before accomplishing the value creation plan. In this article, we use the hazard model to investigate the magnitude of the impact of market conditions on the exit rate of PE deals in Brazil, a volatile emerging economy, and if it increases the chances of exiting investments with holding periods shorter than two years. We analyze a sample of 470 PE deals invested between 1994 and 2014, and we investigate four variables related to market conditions: the stock market priceearnings ratio, the number of IPOs, the Brazilian real (the Brazilian currency) appreciation against the US dollar and the Brazilian interest rate. Our results show that favorable market conditions more than double the exit rate and increase the probability of quick flips.
\end{abstract}

Keywords: private equity; market timing; hazard model; exit; holding period. 


\section{Introduction}

Private Equity (PE) investment has been increasing globally, reaching US $\$ 582$ billion in 2018. In December 2018, there was US $\$ 2$ trillion available for new PE investments (Bain and Co., 2019). Those funds are active investors, which buy equity or quasi-equity stake in potentially high-growth companies, which are usually private and with many operational inefficiencies (Muscarella \& Vetsuypens, 1990). Besides providing capital, PE funds help the growth of the investee companies by hiring talented board members and managers, improving governance and managerial processes, participating actively in the board of directors, forcing the adoption of budget and payfor-performance compensation, giving access to the investors' networks and to extra funding sources, thus requiring periodically audited information (Latini, Fontes-Filho, \& Chambers, 2014; Masulis \& Thomas, 2009).

Before investing in a company, PE funds often negotiate a value creation plan with the business owner(s) and management, and they require covenants in the shareholder agreement regarding control rights (Kaplan, Martel, \& Stromberg, 2007). PEs do not get involved in daily operations. Instead, they participate actively in the board by creating sub-committees for the key processes to implement the negotiated plan, determining accountability for the processes and appointing and firing C-level executives if necessary (Latini et al, 2014; Lerner, Leamon, \& Hardymon, 2012). PE funds provide smart money to companies. Besides financial resources, they bring efficiency gains, managerial processes, better corporate governance practices, and innovation to their investees. However, the model has limitations, and a major one is the potential misalignment between fund managers and company owners regarding exit timing.

PE funds usually have a finite life (ten years), and raise capital from institutional investors and wealthy individuals. During their lives, PE funds have to find interesting companies, invest in them, create value and exit the investments by selling their equity stake. If PE funds return the capital to their investors with a profit, they are eligible for a performance fee, called carry. Therefore, the exit is crucial for PE funds. Investors will only get a return on their capital after the investments have been liquidated, hopefully with a profit, and if this is the case, the fund will receive the performance fee and generate a track record (Lerner et al., 2012). PE firms need good track records to raise new funds and perpetuate themselves. There is performance persistence in the PE industry, and investors interpret past performance as a skill (Kaplan \& Schoar, 2005). The pressure to exit may create misalignments between the private equity fund and the investee company's owner. The optimal horizon to implement the value creation plan in the company may differ from the PE fund's ideal investment holding period.

There are basically 5 exit alternatives: sale to another company (trade sale); IPO (capital market); sale to another PE fund (secondary sale); sale to the owner; and write-off (bankruptcy and sale to owners for an insignificant value). The first two alternatives, trade sale and IPO, are considered the most successful, with higher returns (Giot \& Schwienbacher, 2007; Johan \& Zhang, 2016; Zarutskie, 2010). Market conditions significantly influence the number of deals and the return of Merger and Acquisition (M\&A) and IPO activities. PE fund managers time the market to sell their investments in higher valuation periods (Cao, 2011), and this may create situations in which

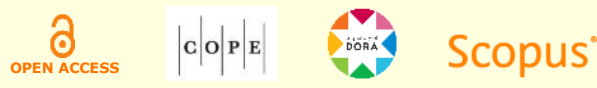


PE funds exit before accomplishing the value creation plan or fully exploring the value creation opportunity. If the company is sold to another company, the owner will usually be forced to sell her or his stake to the PE fund, and if the sale is premature, the value creation plan will generally not be fully accomplished. In this case, the owner will receive a lower valuation for her or his stake. In the case of IPOs, the pressure to exit may prematurely push a company to an IPO, thus increasing the risk of failure and underpricing (Gompers, 1996).

In emerging economies, hot market windows are shorter and less frequent than in developed countries, and therefore fund managers have an even higher incentive to time the market. Brazil, for instance, had an IPO boom between 2004 and 2008, and 39\% of the IPOs were backed by PEs (Minardi, Ferrari, \& Tavares, 2013). PE funds benefit from hot market windows to achieve more profitable exits. The majority of the PE investors in emerging economies are international, and therefore the exchange rate should also have an impact on the exit rate.

Understanding the dynamics of exits is an important issue in PE investments. The exit rate is dependent on the time that the company has been part of the fund's portfolio. If the fund has recently acquired the company, it will need more time to implement the value creation plan, and the chances of exiting the company are little. As time goes by, the exit rate should increase with the implementation of the value creation plan. Therefore, we cannot analyze exit timing without taking into account the period that the PE fund has held the company in its portfolio. According to Cao (2011), investment return increases with the holding period, but with a concave function. The holding period must be long enough for the fund to implement the value creation plan. However, a holding period that is too long has a negative effect on the IRR (internal rate of return), and, consequently, on performance fees and track records. Besides this, PE funds have a finite life, usually around 10 years, and the longer the investment stays in the portfolio, the closer it comes to the end of a fund's life. Extremely long holding periods may indicate difficulties in selling (Giot \& Schwienbacher, 2007). Therefore, we should expect low exit rates for short holding periods, and high exit rates for long holding periods. As private equity funds intend to exit at some point in time, even proprietary funds, which does not raise capital with investors and does not have a finite life, will eventually sell their stake in the portfolio company.

Private equity is a fairly recent industry in Brazil, and Brazilian PE organizations need to prove that they can generate good returns in the country. Therefore, the pressure to exit in hot market windows is strong, and fund managers may liquidate their stake in the company even before implementing the value creation or restructuring plans. This is not optimal for the investee company, and it may create conflicts between the PE fund's manager and the business owner. The objective of this article is to investigate how market conditions impact PE exit rates in Brazil, and if this significantly increases the chances of quick flips; that is, exit investments with holding periods shorter than two years. In a horizon shorter than two years, it is very probable that a PE fund has not had enough time to prepare the company well for growth and has not accomplished the value creation plan yet.

We use the hazard model to estimate the market condition effect on the exit rate. This methodology allows us to adequately control for the investment holding period. We adopt four

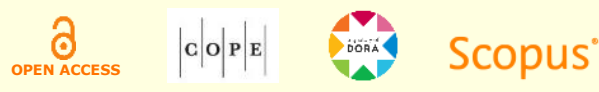


variables related to market conditions: the price-earnings ratio, the number of IPOs, the Brazilian real appreciation against the US dollar, and the Brazilian interest rate. We also control our analysis for deal size, fund manager experience, fund strategy (buyout or growth), the time of the investment in relation to the fund-raising date, sector, and the year of investment.

This analysis, which takes the exit dynamic into accounting, is a pioneering one in Brazil and it contributes to the emerging market literature of Private Equity. As part of the BRICS block, Brazil is one of the emerging economies that has raised the most private equity capital in the last decade. It is also the largest capital market in Latin America. This article also contributes to a better understanding of the exit dynamics, an important tool for liquidity analyses for private equity investors. By incorporating these relevant factors into simulation models, investors can better predict cash flow patterns and liquidity issues. Business owners can also better estimate the risk of an anticipated exit by a PE fund.

Our results indicate that PE fund managers in Brazil time the market significantly. The exit rate increases by around two times in moments of high market price-earnings ratio, with high numbers of IPOs, and moments of Brazilian currency appreciation against the US dollar. This is also true for holding periods less than two years. A higher interest rate decreases the exit rate by roughly $60 \%$. Our findings are in accordance with the hypotheses of market timing and grandstanding. Fund managers may exit before an optimal holding period in order to generate good track records.

\section{Literature Review and Hypothesis Formulation}

\section{Private equity in Brazil}

The dominant target for PE funds in such emerging markets as Brazil are family-owned companies, managed by the first or second generation of the founding families (Zeisberger, Prahl, \& White, 2017). These companies are often less formal, facing financial capital constraints, underdeveloped capital markets and a weak institutional environment (Latini et al., 2014; Wright, Amess, Weir, \& Girma, 2009). Family-owned companies in emerging markets can benefit substantially from Private Equity investment. Besides providing funding, PEs can increase their efficiency. There is international evidence that PE funds contribute substantially to the improvement of corporate governance and to the operational performance of the investee companies (Helman \& Puri, 2002; Masulis \& Thomas, 2009; Muscarella \& Vetsuypens, 1990).

The PE industry is fairly recent in Brazil. Although the first PE firm was founded in the early 1980s, the development of the PE industry started with the economic stabilization and privatization program brought by the Real Plan in mid-1990s (Mariz \& Savoia, 2005; Ribeiro \& Carvalho, 2008). In 2017, according to KPMG and ABVCAP (2018), the accumulated committed capital in Brazilian PE was $\mathrm{R} \$ 154.3$ billion, and the capital available for new investments was $\mathrm{R} \$ 30.7$ billion. The exchange rate at the end of 2017 , on December 29, was US $\$ 1$ to $R \$ 3.31$. There is a high potential for the growth of the Brazilian PE industry. In 2017,

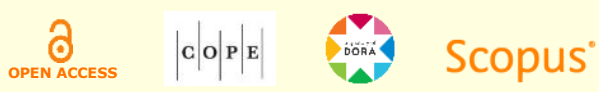


according to KPMG and ABVCAP (2018), PE investments represented $0.26 \%$ of the Brazilian GDP, which is quite modest in comparison to the UK (1.28\% of GDP) and the USA (1.65\% of GDP). There is also a high concentration of investments and location of PE firms in southeastern Brazil (Carvalho, Galucci Netto, \& Sampaio, 2014), where São Paulo, the largest business center in Latin America, is located.

It is important to investigate the quality of the PE firm before committing capital. The PE firm's track record, the experience and accomplishment of the PE partners' team, and governance procedures are important issues in the investment decision process (Mariz \& Savoia, 2005). In general, the Brazilian PE industry has delivered good returns: $22 \%$ of gross IRR in US\$, but with a lot of dispersion. The difference between the mean IRR of top and bottom quartile is around 60\% (Minardi, Kanitz, \& Bassani, 2014). Carvalho, Gallucci-Netto and Siqueira (2017) investigated the determinants of success in private equity investments in Brazil and found that bank affiliated funds underperformed those managed by independent organizations. In some Brazilian funds, investors participate in the investment committee and in the investment and divestment decision, which is not common in the international market. This Brazilian idiosyncrasy negatively impacts PE investment performance. The authors also found evidence that investments in which the fund has a controlling stake have higher returns.

The literature indicates that PE funds improve the governance and better prepare companies for IPOs in Brazil. Black, Carvalho and Sampaio (2014) found that PE-backed IPOs scored higher in board procedures than non-PE backed IPOs, especially in the ability to create and implement Clevel performance evaluation systems, and covenants to govern the Board. Gioielli, Carvalho and Sampaio (2013) show that private equity-backed IPOs have higher quality auditors and show significantly less earning management than non-PE backed IPOs. Latini, Fontes-Filho and Chambers (2014) find that PE funds promote good governance practices in Brazilian SMEs, especially related to the composition and performance of the Board of directors, protection of minority shareholders' rights and the standardization of management and financial reporting. However, such issues as agent incentives (stock options), decoupling of CEO and chairman position, existence of succession plans, and separation of family members with controlling position from executive positions do not show the same level of implementation. Rossi and Martenlanc (2013) compared various operational and financial indicators three years preceding and following the IPO for PE sponsored companies to non-PE sponsored companies. The finding indicated that PE sponsored companies outperformed non-PE sponsored ones. Minardi, Ferrari and Tavares (2013) found that the cumulative abnormal returns of PE-backed IPOs outperform non-PE backed IPOs one year after issuing.

The pressure for a good exit may generate conflicts of interest between PE funds and companies' shareholders. Artica, Insper and Endeavour (2017) conducted a survey with 46 Brazilian familyowned companies, which received PE investments and had an exit. All but one business owner would recommend PE investments to other business owners. However, 2/3 of them reported conflicts during the investment period, and among the main reasons, they cited misalignments regarding the timing and route of exit of the PE fund. Our objective with this article is to

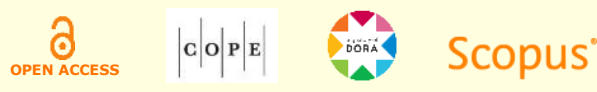


contribute to the literature on PE in Brazil, analyzing the PE exit dynamic and how market conditions impact exit rates.

\section{Literature related to the dynamics of PE exit and hypotheses formulation}

Exit is a crucial issue in PE due to the finite life of the fund, the importance of carry in the PE fund compensation and the need for track records to raise a new fund. There are two main theories which discuss potential conflict of interest in the PE exit decision: market timing hypothesis and grandstanding.

Cao (2011) investigates the market timing hypothesis in a sample of Initial Public Offers (IPO) backed by Leverage Buyout (LBO) funds in the USA. LBO funds usually acquire a control equity stake in companies that generate cash flows, but have operational inefficiencies and bad management. The acquisitions are highly leveraged transactions (sometimes with a debt-to-asset ratio higher than $80 \%$ ). After implementing the restructuring program, the LBO fund sells its stake in the company through an IPO or to another company (Lerner et al., 2012). The IPO operation backed by an LBO fund is called reversed leverage buyout (RLBO). According to the market timing hypothesis, in order to achieve a higher selling price and a higher return, LBO funds take advantage of hot capital market windows to bring companies to an IPO, even before concluding the restructuring process. Therefore, market conditions can create perverse incentives. By looking for a quick return, PE funds may use less time than necessary in the restructuring process, bringing immature companies to an IPO. This phenomenon is called quick flips. The authors analyzed 594 RLBO transactions issued between 1981 and 2006. They find evidence that under favorable market conditions, LBO funds tend to perform quick flips more often and to reduce portfolio companies' holding period. Stromberg (2008) analyzes a global sample of 30,000 LBO transactions. He concludes that LBOs financed by more experienced PEs have shorter holding periods, but the companies with a holding period shorter than one year represent less than $2.9 \%$ of the sample.

Another perverse incentive is Grandstand. According to Gompers (1996), less experienced fund managers have an incentive to bring companies prematurely to IPOs to acquire track records and raise new funds. This generates conflicts of interest with PE fund investors (limited partners) and the new shareholders that will acquire shares in the Stock Exchange. Grandstand increases underpricing, decreases the investment potential return and allows shareholders to risk the purchase of shares in poorly performing companies. The author analyzed 433 IPOs issued between 1978 and 1987 and found evidence supporting Grandstand. Companies backed by less experienced VCs were younger at the IPO time and had higher underpricing.

Giot and Schwienbacher (2007) point out that PE funds are concerned with the exit alternative and the time they will hold the company in the portfolio before selling it. They investigate the dynamics of the following exit routes: IPO, sale to another company and write-off, as well as the holding period determinants. Their sample has roughly 6,000 VC deals. They use the competitive risk hazard model approach, and their results indicate that the exit rate for an IPO is concave. According to the results, the fund quickly selects the candidates for an IPO, but if the listing in

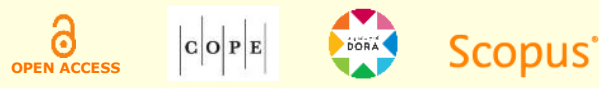


the stock exchange is not fast enough, the probability of bringing the company to an IPO plummets. For a trade sale, the exit rate achieves its maximum value after a longer holding period as compared to IPOs. According to the authors, this is in line with the notion that the sale to another company is a more universal exit channel. The authors also analyze the impact of market conditions on the exit dynamics. Their results show that in a hot market condition, or when the IPO condition is more favorable, the exit rate is accelerated. The funds are probably looking forward to capitalizing the best exit alternatives.

Jenkinson and Sousa (2015) investigate three exit alternatives for the European PE industry: IPO, trade sales and secondary sales, and three factors that determine the choice: market condition, fund structure, and structure of the invested company. According to the authors, funds try to achieve the best possible selling price, and the market condition generates different windows of opportunities to exploit it. If the IPO market is cold, the credit market is hot, and PE funds have a lot of dry powder (capital available for investing in companies), the most interesting exit alternative will probably be a secondary sale. Therefore, if a credit condition is favorable, the probability of exiting to a secondary sale increases. However, if there is a window of opportunity in the capital market, funds will tend to exit through IPOs. If the fund's life approaches its expiration, there will be a pressure to exit. Masulis and Nataha (2009) find evidence in the M\&A market that the acquiring company's return increases when the seller is a PE fund whose life is close to its expiration. If the portfolio company is not mature enough for an IPO, the chances for a trade sale or a secondary sale increase. Funds are also specialized in different stages of the company life cycle. Funds focused on the latter stage can acquire the equity stake of funds focused on the earlier stage. Higher-leveraged companies are targets for other PE funds. More profitable companies and those that need less monitoring are targets for IPOs, and the less-profitable ones are targets of $M \& A$.

Jenkinson and Souza (2015) find evidence that factors related to a market condition are the most important determinants of the exit route. PE funds exploit windows of opportunities that are opened in different moments. PE tends to choose an IPO to anticipate an exit, since it signals good performance to the market, and consequently helps with the raising of a new fund. This is in accordance with the Grandstand theory (Gompers, 1996). However, if it is not possible to bring the company to an IPO in a reasonably short period, funds prefer to exit through another company or to another PE fund, sustaining the evidence from Giot and Schwienbacher (2007).

Based on the market timing hypothesis, PE funds should exploit market conditions to sell the company at a higher price. Favourable market conditions should increase the probability of quick flips (exits with a holding period shorter than two years). Quick flippers are candidates for investments in which the PE exits before accomplishing the value creation plan, thus creating misalignment with the business owner.

As the Brazilian PE industry is relatively young, funds need good exits to generate reputation, and according to the grandstand theory, they may prematurely push companies to IPOs. As hot market windows are very volatile, grandstanding combined with the market timing hypothesis

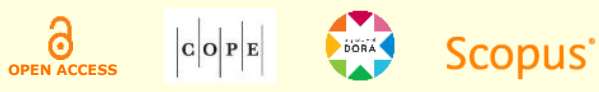


substantially increases the chances of prematurely exiting an investment. We have therefore two basic hypotheses:

H1: Favorable market conditions will increase the exit rate of investments.

H2: Favorable market conditions will increase the rate of quick flips.

According to Jenkinson and Souza (2015), a favourable market condition of the stock market increases the chances of an IPO. Therefore, we will test how the stock exchange price-earnings ratio and the number of IPOs impact the exit rate. Low interest rates increase the chances of a secondary exit, as well as a trade sale (Jenkinson \& Souza, 2015). We will test how the level of Brazilian interest rates impacts exit rate.

Most PE capital is raised with foreign investors. In 2017, 58\% of the PE capital for Brazil was international (KPMG \& ABVCAP, 2018). When PE funds raise capital in US dollars or in another international currency, they run the foreign exchange risk. They call the capital in US dollars and exchange it to Brazilian reais to invest in the portfolio companies. When PE funds sell their equity position, they are paid in Brazilian reais, and they convert it to US dollars in order to wire transfer the capital to foreign investors. The Brazilian reais exchange rate is very volatile, and currency risk is one of the highest risks incurred by Brazilian PE funds (Minardi, Kanitz, Bassani, \& Schittkowsky, 2017). Therefore, funds will benefit from Brazilian real appreciation to sell to strategic buyers, or to partially sell through an IPO. We also investigate the impact of Brazilian foreign exchange rate on the exit rate.

\section{Methodology and Database}

\section{Econometric model}

We used the hazard model to determine the exit rate of PE funds in Brazil. This model is also known as the duration model and the survival model (see Kiefer, 1988 and Greene, 2000 for more details). Giot and Schwienbacher (2007) and Jenkinson and Souza (2015) used the hazard model to analyze the exit dynamics of VC funds. Gejadze, Giot and Schwienbacher (2017) used the hazard model to investigate what determines the time the fund was raised, and Ljungqvist and Richardson (2003) used hazard models to investigate the dynamic of the time the PE fund takes to invest in portfolio companies.

The central concept in a duration model is the conditional probability that an observation will fail in period $T$, given that it has survived $t-d t$ periods, and it is called the hazard function, $\lambda$. In the case of PE exits, the hazard function is equivalent to the probability that the fund will sell its stake in a company in period $\mathrm{T}$, given that the fund has been holding this company in its portfolio for $t-d t$ periods. Therefore, the hazard function corresponds to the marginal exit rate. As the conditional probability of exit will change with the investment duration (the holding period of 
the deal), the hazard is function of $t, \lambda(t)$, as in equation (1), where $f(t)$ is the failure function and $\mathrm{S}(\mathrm{t})$ is the survival function.

$$
\lambda(t)=\frac{f(t)}{S(t)}
$$

The definition of duration requires an origin (initial time), a time scale and a precise definition of the event that ends the duration. In the case of PE exits, the origin is the day the fund performs the investment, and the event that brings the duration to an end is the sale of the investment. We adopt semesters as a time scale. Observations can fail only once, according to our hazard model. Therefore, we considered only total sales, excluding partial sales.

For the companies that were sold, we observe the day the PE fund invested in it and the day the fund sold it. However, some companies were still in the funds' portfolios when we stopped our analysis, and we do not know how long these PE funds will hold them in their portfolio. Therefore, the observations that have not had an exit by the day the data collection stopped are right censored. In order to distinguish between censored and non-censored observations, we include an indication variable $\mathrm{d}$, that assumes value 1 when the observation is not censored, and value zero if the observation is censored. Equation (2) expresses the log likelihood function.

$\operatorname{LnL}(\theta)=\sum_{i=1}^{n} d_{i} \ln f\left(t_{i}, \theta\right)+\sum_{i=1}^{n}\left(1-d_{i}\right) \ln S\left(t_{i}, \theta\right)=\sum_{i=1}^{n} d_{i} \ln f\left(t_{i}, \theta\right)-\sum_{i=1}^{n} \Lambda\left(t_{i}, \theta\right)$

Where $d_{i}$ has value 1 if the deal had an exit and zero otherwise (right censored observation); $\theta$ is the vector of the parameter specification of the hazard distribution. The non-censored information contributes to the fail density term, that is, having being sold in $t_{i}, f\left(t_{i}, \theta\right)$, and the censored observation with the survival density term, that is, with the fact that they have not been sold in ti, $S\left(t_{i}, \theta\right) . \Lambda(t)$ is the hazard integrated function.

We adopt the parametric approach for the hazard model, $\lambda$, using the Weibull distribution, which is more general than the Exponential distribution (Kalbfleisch \& Prentice, 2002). The Weibull basic hazard function is $\lambda_{0}(\mathrm{t})=\mathrm{p} \theta \mathrm{t}^{\mathrm{p}-1}$, where $\theta$ is parameterized as $\theta_{\mathrm{i}}=\exp \left(-\mathrm{px} \mathrm{x}_{\mathrm{i}} \beta\right)$. If $\mathrm{p}=1$, this function reduces to the Exponential.

The proportional effect of $\mathrm{x}$ in the conditional probability of ending a duration does not depend on the holding period. Therefore, the coefficients can be interpreted as the effect of $\mathrm{x}$ on the conditional probability of ending a duration. The coefficient signal indicates the impact direction of the explanatory variable on the conditional probability of ending a duration. Thus, the hazard is rising if coefficient $>1$, and declining if coefficient $<1$. 


\section{Database and variables}

Our data was provided by Spectra Investment, a private equity investor in Brazil. The information is mostly based on PPM (Private Placement Memorandum), which are documents used by fund managers to raise new funds with institutional investors. Investors have access to PPMs of PE organizations which are raising capital, independently if they decide to invest or not. PPMs contain information regarding characteristics of current and previous deals and funds of the PE organization. As PPMs are eligible for due diligence, PE organizations have to report successful and unsuccessful investments. Spectra Investment also completed the database with information from the CVM (Comissão de Valores Mobiliários - Brazilian Security Exchange Commission) and other sources. The information in PPMs are confidential, and Spectra has protected the identity of fund managers, funds and deals, but the coding allowed for information crosschecking.

The sample has information on 82 Brazilian and international fund managers, which represents $43.85 \%$ of the 187 managers mapped by KPMG and ABVCAP (2018). The survivorship and selection bias are not severe. The data includes successful PE firms (72\% of the firms existed for 5 years or more and $22 \%$ raised 4 or more funds) as well as PE firms that are inactive or closed their operation (13\% of the firms have not raised a new fund in the last ten years). The sample is representative of the Brazilian PE industry. It includes investments with control and minority stakes, investments that had an outstanding performance (higher than a gross IRR of $100 \%$ ) as well as write-offs, investments in SME and large companies (tickets range from US $\$ 190$ thousand to US\$608 million).

We excluded write-offs from the sample, since the database does not contain information on the date the fund recognizes the loss. We also excluded deals invested before 1994, since it was a period characterized by high economic uncertainty and instability, and the PE industry was practically inexistent at that time. The VC industry was rather underdeveloped in Brazil before 2010 (see Foster \& Morris, 2015), and most of the investments closed after that period are still in the VC fund portfolios, or have been written off. The write-off rate of the deals invested before 2010 is also high. Therefore, we have relatively few exits observation with holding period information, and thus we preferred to exclude VC deals (investments in companies that have not reached the breakeven yet) from the sample.

The final sample contains 470 PE deals with entry dates between 1994 and 2014, of which 181 were fully liquidated or went to IPO. Figure 1 shows the number of investments and divestments according to the year of origination. Almost all deals originating before or in 2006 were divested, and therefore not censored. Practically all recent deals (invested after 2011) are censored. 


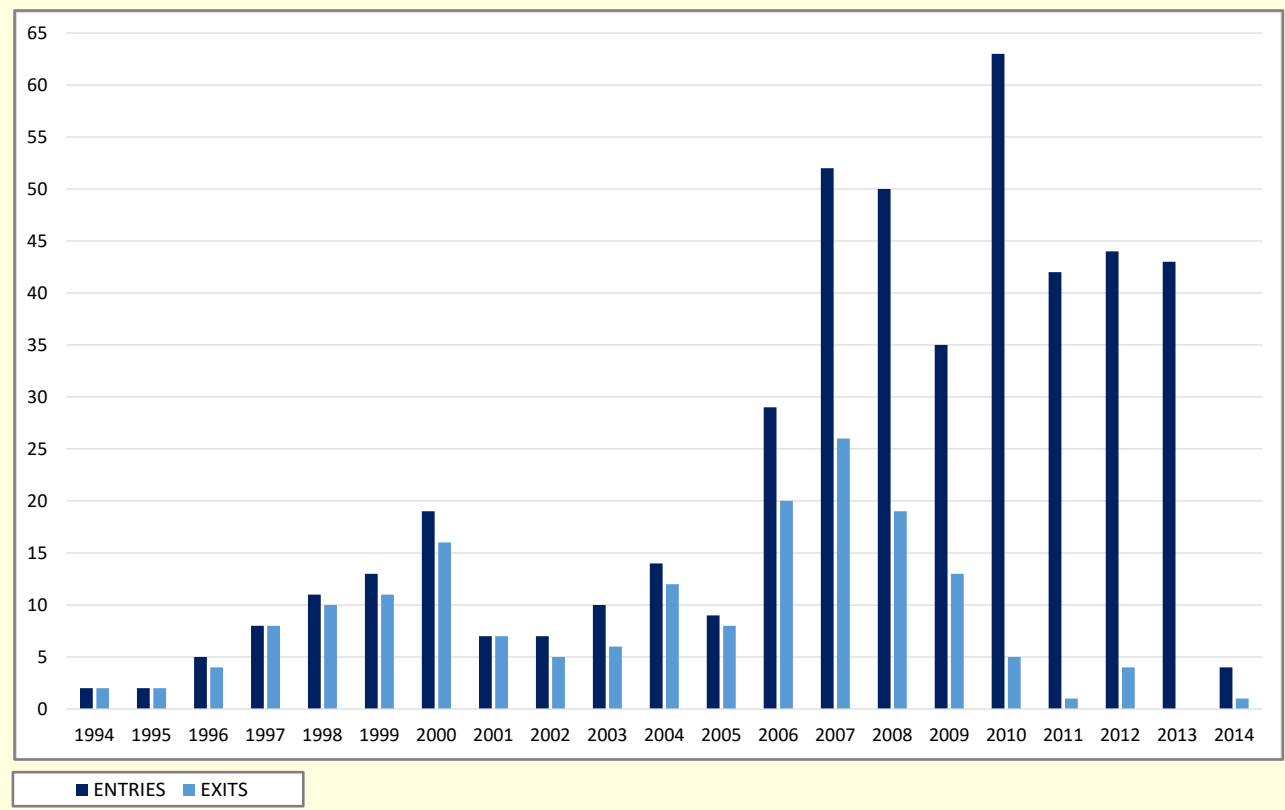

Figure 1. Number of investments and exits of PE funds according to the year of investment

For the basic hazard model, we used the following variables:

- $\mathrm{d}$ : variable that assumes value 1 if the investment had an exit (non-censored) and 0 if it is still in the fund's portfolio (right censored). We have 181 deals with an exit and 289 without an exit.

- t: period in semesters the deal stays in the fund portfolio. For the non-censored observations, it corresponds to the holding period. We estimated it as the difference in semesters between entry date and exit day. Exit rate should increase with $t$. For the censored information, $t$ was estimated as the difference between entry date and the last day the data was collected: March $1^{\text {st }}, 2015$.

\section{Variables related to market condition}

We collected in Economatica monthly Price-Earnings ratios of all stocks traded in B3, calculated with the monthly closing price and the consolidated twelve-month financial statement. As small companies are an important benchmark for PEs, we did not exclude stocks based on low traded volume. Instead, we excluded all observations with Price-Earnings ratio lower than zero or higher than 100 . This was a way to control for unrealistic ratios due to low liquidity of some stocks. We estimated the stock market Price-Earnings ratio as the equal-weighted average of all Price-Earnings of the month.

Figure 2 contains the evolution of the Brazilian stock market Price-Earnings ratio. Note a peak in 2007, in accordance with the overheated stock market of that period; a valley in 2008 and 2009 in accordance to the global crises, and a recovery in 2010. 


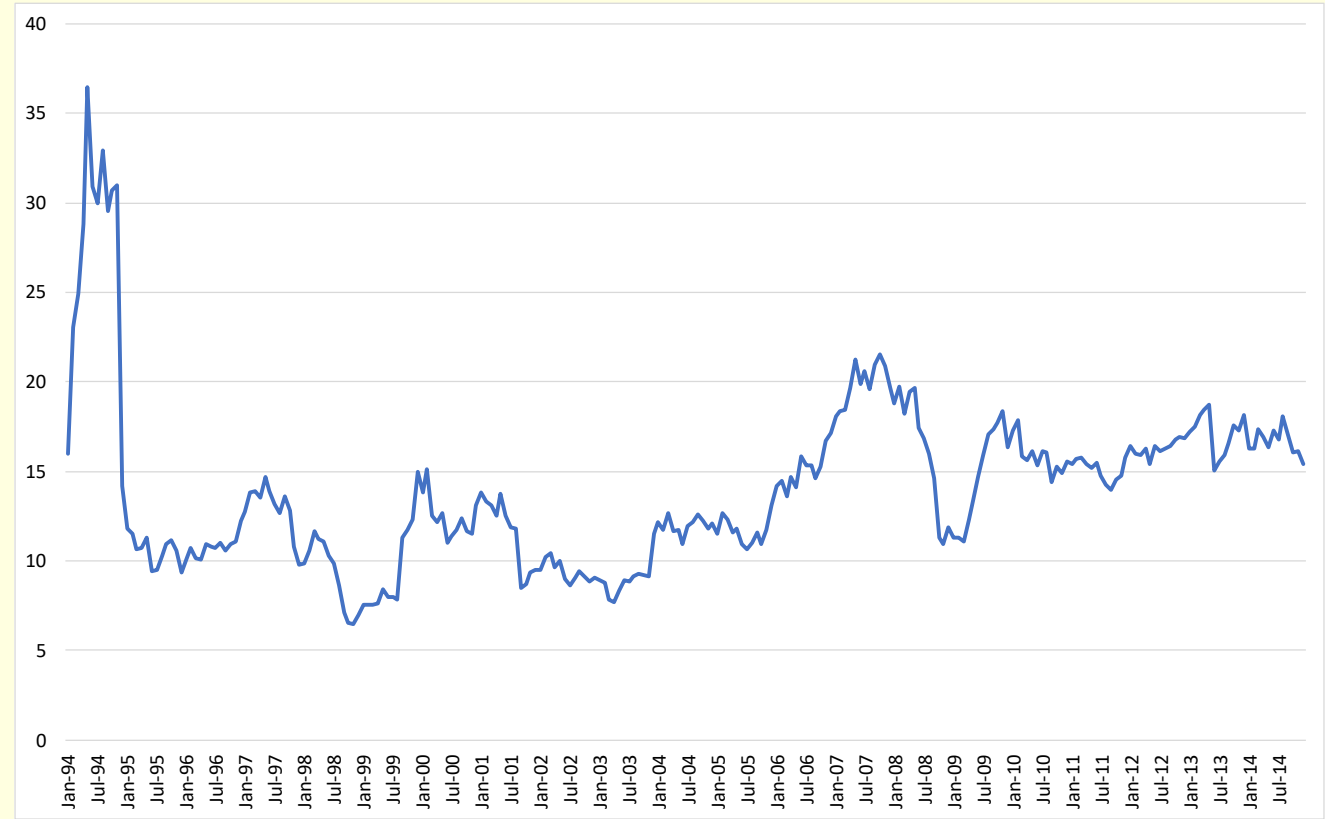

Figure 2. The evolution of the Brazilian stock market price-earnings ratio

We estimated three variables which use price-earnings ratio as a proxy for market condition:

- HOT_PE: a dummy variable with value 1 if the month of the exit is hot for the Brazilian stock market and 0 if it is cold. We classified the month as hot for the financial market if the priceearnings ratio of that month is higher than the average of the price-earnings ratio of the last twelve months, and observed that 77 companies had exit in HOT_PE and 104 in cold ones.

- HOT_PE NAIC: a dummy variable with value 1 if the month of the exit is hot for the specific sector of the corresponding company, and 0 otherwise. We aggregated all stocks of the financial sector (NAIC 52) and classified the month as hot for the financial market if the priceearnings ratio of that month is higher than the average of the Price-Earnings ratio of the last twelve months. We repeated the same procedure for all other sectors, aggregating by the first digit of the NAIC. There are 73 deals with exit in hot months and 108 in cold ones.

- HOT_PE24: we repeated the same procedure used to estimate HOT_PE, but using the average of the price-earnings of the last 24 months, instead of the 12 previous months.

The other market condition variables were estimated as follows:

- HOT_IPO: a dummy variable with value 1 if the month of the exit has a number of IPOs higher than the average in the 6 previous months. We collected the number of IPOs in the month from CVM. There are 60 exits in hot IPO markets and 121 exits in cold IPO ones.

- HOT_FX: a dummy variable with value 1 if the month of the exit has a Brazilian real appreciation against the US dollar higher than the average in the 6 previous months. We used 
the Ptax (US Dollar-Brazilian Real offer exchange rate disclosed by the Brazilian Central Bank) to calculate the monthly Brazilian real appreciation. There are 84 exits in moments of current high appreciation, and 97 in low appreciation or currency devaluation.

- HOT_IR: a dummy variable with value 1 if the month of the exit has an interest rate higher than the average in the 6 previous months. There are 81 exits in moments of high interest rate and 100 otherwise. We used the SELIC as a proxy for the Brazilian interest rate.

Based on the literature, we selected the following control variables:

- AGE: proxy for experience of the PE firm at the time of the investment. It is measured as the difference in years between the PE firm founding year and the year in which the investment occurred. An experienced PE has higher connections with investment banks and has been engaged in many M\&A and IPO deals. Therefore, it should be able to better exploit windows of opportunities (Stromberg, 2008).

- TICKET: value in dollars of the investment made by the PE firm when acquiring the stake of the portfolio company. It is a proxy for the life stage of the company. Funds focused on SMEs have a higher probability to exit by selling its stake to funds focused on larger companies (Jenkinson \& Souza, 2015).

- CONTROL: dummy variable that equals 1 if the PE firm has a control stake in the portfolio company and $\mathrm{O}$ otherwise. When acquiring the control of the company, the PE fund has to pay a control premium. We expect that control deals stay longer in the fund portfolio, because the value creation plans are more aggressive to compensate for the higher entry price, thus demanding a longer implementation time (Valkama, Maula, Niloskelainen, \& Wright, 2013).

- INV_TIME: the time difference in semesters between the date of the first deal of the fund and the entry date of the observation. In case the observation corresponds to the first deal of the fund, this variable has value 0 . It is a proxy for the interval of time between fund inception and the investment date. The larger it is, the shorter the distance until the expiration date of the fund, and consequently the higher the pressure to exit (Jenkinson \& Souza, 2015).

- Sector dummies. We controlled for the most popular sectors in Private Equity during the analyzed period: Real Estate, Finance, Education and Oil and Gas.

- Year dummies: We established dummy variables for entry years according to the different private equity cycles discussed by Ramalho, Furtado and Lara (2011): 1994-1997 - when the PE industry started to have a significant activity, but fund managers were inexperienced and the ecosystem was immature; 1998-2001 - in 1998 there was a significant Brazilian currency devaluation, which combined with a lack of fund managers' inexperience resulted in many unsuccessful exits. The industry calls this period nuclear winter because of the unfriendly environment to raise PE funds dedicated to Brazil; 2002-2006 - high liquidity in the world. Many PE firms raised funds, and the IPO market window opened after 2004; and 2007-2010

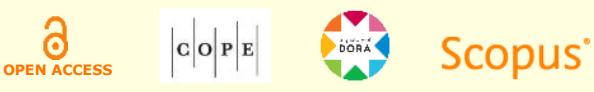


- 2007 experienced a boom of IPOs. There was a global crisis in 2008, but Brazil was not severely affected, and the IPO window was not completely shut down, and funds dedicated to Brazil raised significant resources.

Table 1 contains a descriptive analysis of the variables. We observe that the PE firm experience is higher in the censored sample. A probable explanation is that most of the censored investments (more recent investments) were made by more experienced PE firms.

Table 1

\section{Descriptive analysis of variables}

\begin{tabular}{|c|c|c|c|c|}
\hline & & Total sample & $\begin{array}{c}\text { Exit } \\
\text { (non-censored) }\end{array}$ & Without exit (censored) \\
\hline Observations & Number & 469 & 180 & 289 \\
\hline \multirow[t]{4}{*}{ Holding period (semesters) } & Mean & & 9.02 & \\
\hline & Std. Dev. & & 6.09 & \\
\hline & Maximum & & 25.69 & \\
\hline & Minimum & & 0.29 & \\
\hline \multirow[t]{4}{*}{ Ticket (US\$ million) } & Mean & 60.86 & 43.53 & 76.04 \\
\hline & Std. Dev. & 84.79 & 70.58 & 93.10 \\
\hline & Maximum & 608.02 & 608.02 & 535.25 \\
\hline & Minimum & 0.19 & 0.19 & 0.66 \\
\hline \multirow[t]{4}{*}{ Age (years) } & Mean & 7.40 & 5.33 & 8.68 \\
\hline & Std. Dev. & 6.77 & 5.24 & 7.29 \\
\hline & Maximum & 47.00 & 32.00 & 47.00 \\
\hline & Minimum & 0.00 & 0.00 & 0.00 \\
\hline \multirow[t]{2}{*}{ Control } & Number & 113 & 55 & 58 \\
\hline & Percentage & 34.45 & 33.54 & 35.37 \\
\hline \multirow[t]{4}{*}{ Time_Invest (semesters) } & Mean & 2.81 & 3.05 & 2.62 \\
\hline & Std. Dev. & 3.36 & 3.49 & 3.26 \\
\hline & Maximum & 19.33 & 19.33 & 19.33 \\
\hline & Minimum & 0.00 & 0.00 & 0.00 \\
\hline
\end{tabular}

The maximum holding period in the sample is 25.2 semesters, and the maximum time difference between the deal investment date and the date of the first investment is 19.3 semesters. Although the majority of the PE funds in the sample have a finite life of around 10 years and an investment period between 3 to 5 years, the sample contains investments by funds with proprietary resources and affiliated with banks, which do not have a finite-life or an established investment period.

Table 2 shows the correlation matrix. We find a positive correlation between holding period and control and between holding period and ticket. We find a negative correlation between holding period and size, and between holding period and time of the investment since fund inception. We also observe a positive and significant correlation between size and experience. This is 
expected because, as PE firms gain reputation, they tend to raise larger funds and migrate to larger deals (Metrick \& Yasuda, 2010).

Table 2

\section{Correlation matrix of variables}

\begin{tabular}{|c|c|c|c|c|c|c|c|c|c|c|}
\hline & HP & Control & Age & Ticket & Time_Invest & Hot_PE12 & Hot_PE_NAIC & Hot_IPO & Hot_FX & Hot_FX \\
\hline Control & 0.18 & 1 & & & & & & & & \\
\hline Age & -0.25 & 0.07 & 1 & & & & & & & \\
\hline Ticket & 0.03 & 0.05 & 0.28 & 1 & & & & & & \\
\hline Time_invest & -0.07 & 0.03 & 016 & 0.01 & 1 & & & & & \\
\hline Hot_PE12 & -0.03 & -0.01 & -0.19 & -0.10 & 0.01 & 1 & & & & \\
\hline Hot_PE_NAIC & -0.04 & -0.03 & -0.21 & -0.13 & 0.00 & 0.66 & 1 & & & \\
\hline Hot_IPO & -0.03 & -0.06 & -0.12 & -0.15 & -0.02 & 0.06 & 0.19 & 1 & & \\
\hline Hot_FX & 0.07 & 0.09 & -0.16 & -0.06 & 0.04 & 0.11 & 0.11 & 0.15 & 1 & \\
\hline Hot_RF & -0.04 & -0.02 & 0.28 & 0.12 & -0.05 & -0.26 & -0.29 & -0.28 & -0.30 & -0.30 \\
\hline
\end{tabular}

Note. Values in bold are statistically significant $(\alpha=5 \%)$.

\section{Results}

Figure 3 plots the cumulative basic survival function of PE deals, not taking the explanatory variables into consideration. It represents the percentage of investments in the fund portfolio according to the holding period. Note that 10 semesters after the acquisition date, $70 \%$ of the deals were in the fund portfolio, and 26 semesters after the acquisition date, $15 \%$ of the deals were still in the fund portfolio. Quick flippers are $7.2 \%$ of the sample: 13 out of 181 exits had a holding period shorter than two semesters. This is high in comparison to the $2.9 \%$ quick flipper rate found by Stromberg (2008) in a global sample of LBO.

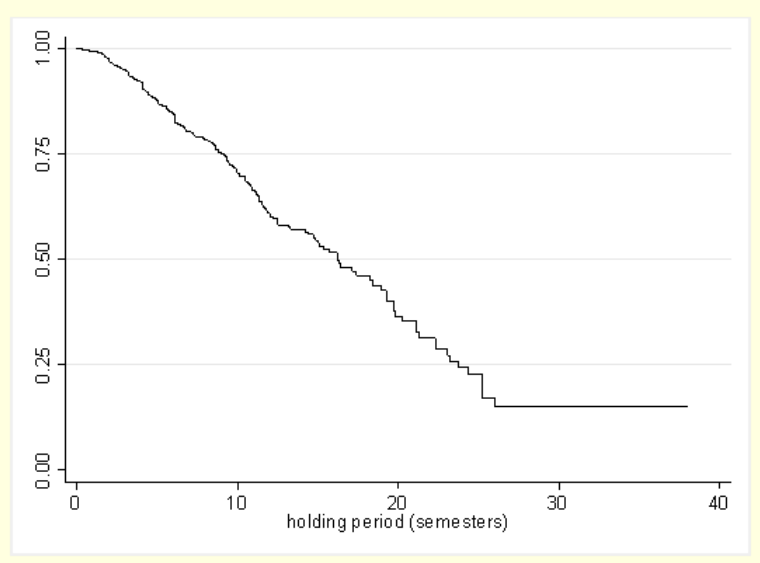

Figure 3. Percentage of deals in the fund portfolio according to holding period

Figure 4 plots the cumulative basic survival function segregated by hot and cold markets according to market condition variables. Panel A contains the analysis for the market condition according 
to the sector Price-Earnings ratio, panel B for high and low number of IPOs, Panel C for the high and low Brazilian real appreciation against the US dollar and Panel D for high and low interest rate. Table 3 contains the percentage of investments in the fund portfolio after 2, 4, 10, 20 and 26 semesters counting from the acquisition date, segregating for hot and cold market condition according to different proxies.

We did not plot the cumulative survival rate segregated by stock market Price-Earnings ratios, because the graphics look very similar to the one in Panel A, which is segregated by sector PriceEarnings ratios. However, Table 3 contemplates the percentage of deals according to different holding periods segregated by those variables.
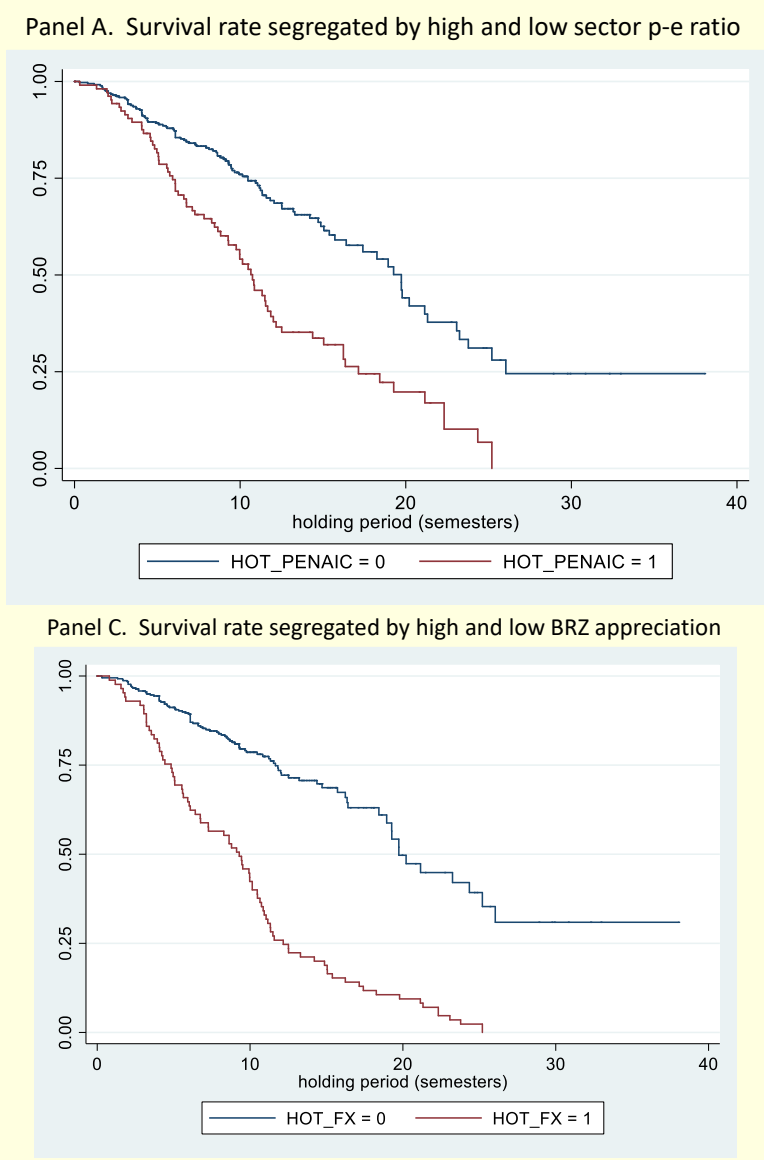

Panel B. Survival rate segregated by high and low numbers of IPOs

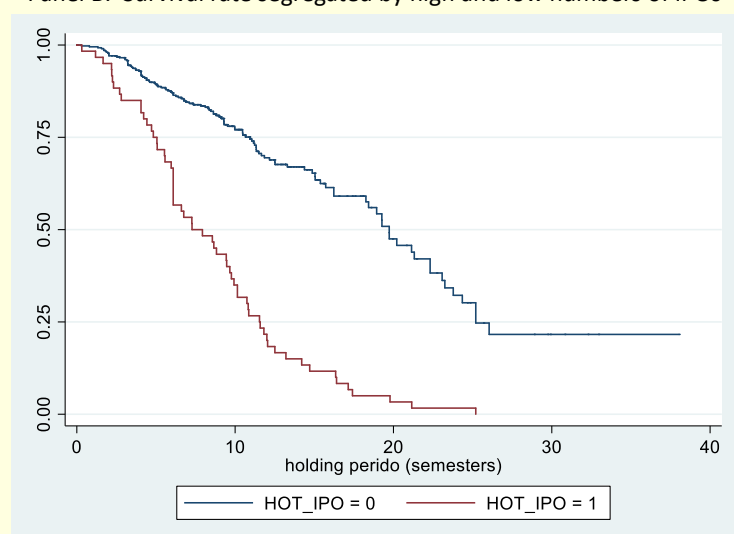

Panel D. Survival rate segregated by high and low interst rate

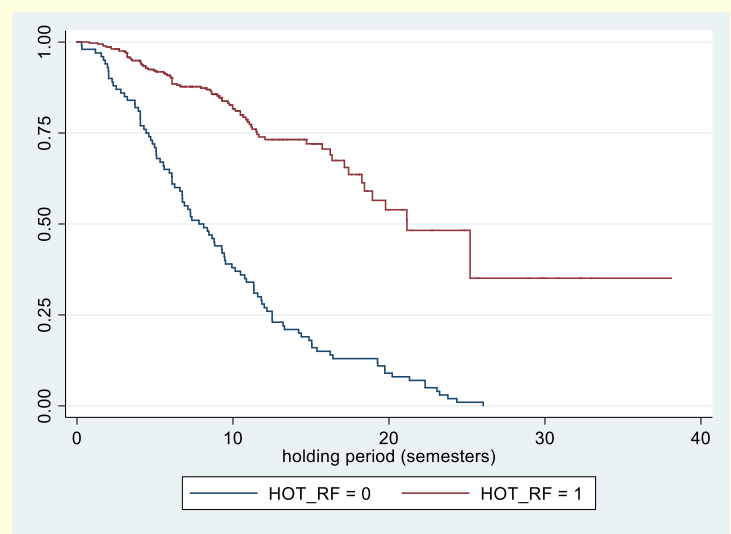

Figure 4. Percentage of deals in fund portfolio according to holding periods and segregated by hot and cold periods 
Table 3

Percentage of deals in the portfolio according to holding periods and market conditions

\begin{tabular}{|c|c|c|c|c|c|c|c|c|c|c|c|c|}
\hline \multirow{3}{*}{$\begin{array}{l}\text { n. of } \\
\text { semesters }\end{array}$} & \multicolumn{10}{|c|}{ Percentage of deals in the portfolio } & & \\
\hline & \multicolumn{2}{|c|}{ HOT_PENAIC } & \multicolumn{2}{|c|}{ HOT_PE12 } & \multicolumn{2}{|c|}{ HOT_PE24 } & \multicolumn{2}{|c|}{ HOT_IPO } & \multicolumn{2}{|c|}{ HOT_FX } & \multicolumn{2}{|c|}{ HOT_RF } \\
\hline & 0 & 1 & 0 & 1 & 0 & 1 & 0 & 1 & 0 & 1 & 0 & 1 \\
\hline 2 & 0.9726 & 0.9619 & 0.9746 & 0.9565 & 0.9786 & 0.9580 & 0.9756 & 0.9333 & 0.9818 & 0.9294 & 0.9200 & 0.9865 \\
\hline 4 & 0.9260 & 0.8851 & 0.9300 & 0.8776 & 0.9527 & 0.8314 & 0.9290 & 0.8167 & 0.9440 & 0.8000 & 0.7900 & 0.9491 \\
\hline 10 & 0.7598 & 0.5280 & 0.7470 & 0.5820 & 0.7756 & 0.5563 & 0.7709 & 0.3167 & 0.7858 & 0.4000 & 0.3700 & 0.8166 \\
\hline 20 & 0.4199 & 0.1976 & 0.4050 & 0.2354 & 0.4844 & 0.1886 & 0.4573 & 0.0333 & 0.4735 & 0.0941 & 0.0800 & 0.5392 \\
\hline 26 & 0.2451 & - & 0.2638 & - & 0.3153 & - & 0.2162 & - & 0.3091 & - & - & 0.3508 \\
\hline
\end{tabular}

Figure 4 and Table 3 show that there are significant differences in the exit rate dynamic during hot and cold market conditions. High price-earnings ratio, high number of IPOs and appreciation in the Brazilian real exchange rate significantly impact the exit rate. Observe that after 26 subsequent semesters of hot market condition there would be zero deals in the fund portfolio. Instead, if there were 26 semesters of subsequent cold market condition, between $21 \%$ and $31.5 \%$ of the deals would remain in the fund portfolio. The probability of selling through IPOs or selling to strategic buyers increases when the number of IPOs and/or the price-earnings ratio (either sector or the stock market as a whole) are high. If the Brazilian real appreciates against the dollar, PE funds will push companies to IPOs or sell them to strategic buyers. High interest rates negatively impact the exit rate. If there were 26 subsequent semesters of high interest rate, there would be $35 \%$ of the deals in the fund portfolio, and zero if there were 26 subsequent semesters of low interest rates. This means that the chances of exiting by selling to another company or to another fund increases when the interest rate goes down. Those results are in accordance with Hypothesis 1, in which hot market conditions accelerate PE exits, and with the findings of Jenkinson and Souza (2015).

The rate of quick flippers is also substantially higher in hot markets. See for instance that $5.6 \%$ (1-0.9440) of the deals would have holding periods shorter than four semesters (two years) if there were four subsequent semesters of Brazilian real depreciation against the US dollar (HOT_FX=0). Instead, $21 \%$ (1-0.7900) of the deals would be sold before two years of its acquisition if there were four subsequent semesters of Brazilian real appreciation. Although the segregation in hot and cold according to other proxies show lower differences in the percentage of quick flippers, those differences are still very significant. The shorter difference in quick flipper percentage in hot and cold periods is for the sector price-earnings ratio (HOT_PENAIC): 7.4\% if there are four subsequent semesters of low sector price-earnings ratio, and $11.49 \%$ quick flippers if there were two subsequent semesters of high sector price-earnings ratio.

Those results are in accordance with the market timing hypothesis and the evidences in Giot and Schwienbacher (2007) and Jenkinson and Sousa (2015). PE funds take advantage of favorable market windows to sell their investments. They confirm Hypothesis 2, in which hot market conditions increase the probability of quick flippers. 
Table 4 contains the results of the log maximum likelihood analysis adopting the basic hazard and the explanatory variables parametrized by the Weibull function according to equation (2). The hazard ratio of 1 means that the variable does not affect the exit ratio. A hazard ratio higher than 1 means that the variable affects the hazard ratio positively, and lower than 1 means that it affects it negatively.

Confirming the findings in Figure 4 and Table 3, all market factors impact significantly (at 1\%) the exit rate. A high stock price-earnings ratio increases the exit rate by 2.12 times (model 3) and a high sector price-earnings ratio by 2.16 times (model 8). A hot IPO and an appreciated Brazilian real have higher significant coefficients: 2.34 (model 4) and 2.62 (model 5) respectively. A high interest rate decreases the chances of exit by $70 \%$ (model 6).

Note that the coefficients of HOT_PE24 (model 10) is 2.51, slightly higher than 2.12, the coefficient of HOT_PE (model 3). This shows that classifying a month as hot or low according to the average of the twenty-four previous months instead of the twelve previous months does not change the results significantly.

When taking all market condition and control variables into consideration, sector price-earnings ratio (model 7) shows a slightly higher coefficient than the stock market price-earnings ratio (model 1), but this difference is not significant. Foreign exchange rate is the factor with the highest coefficient in models (1) and (7), significantly meaning that PE funds in Brazil try to sell in moments when the Brazilian real is appreciated.

Confirming Jenkinson and Souza (2015), market conditions were much more relevant to explain the exit dynamic than deal or fund characteristics. We find weak evidence (at 10\% level) that the acquisition of control reduces the exit rate by around $25 \%\left((1-0.75)^{*} 100-\right.$ see model 7$)$. 
Table 4

\section{Hazard model analysis}

\begin{tabular}{|c|c|c|c|c|c|c|c|c|c|c|}
\hline \multicolumn{11}{|c|}{ Models } \\
\hline Variables & (1) & (2) & (3) & (4) & (5) & (6) & (7) & (8) & (9) & (10) \\
\hline \multirow[t]{2}{*}{ Hot_PE } & $1.81^{* * *}$ & $1.61^{* * *}$ & $2.12^{* * *}$ & & & & & & & \\
\hline & 0.29 & 0.24 & 0,35 & & & & & & & \\
\hline \multirow[t]{2}{*}{ Hot_PENAIC } & & & & & & & $1.91^{* \star *}$ & $2.16^{\star \star *}$ & & \\
\hline & & & & & & & 0.33 & 0.38 & & \\
\hline \multirow[t]{2}{*}{ Hot_PE_24 } & & & & & & & & & $1.90^{* * *}$ & $2.51^{* \star *}$ \\
\hline & & & & & & & & & 0.29 & 0.42 \\
\hline \multirow[t]{2}{*}{ Hot_IPO } & $1.90^{* * *}$ & $2.74^{\star * *}$ & & $2.34^{* * *}$ & & & $1.82^{* * *}$ & & $1.94^{* * *}$ & \\
\hline & 0.34 & 0.45 & & 0.43 & & & 0.30 & & 0.35 & \\
\hline \multirow[t]{2}{*}{ Hot_FX } & $2.13^{\star \star \star}$ & $2.55^{\star \star \star}$ & & & $2.62^{\star \star \star}$ & & $2.02^{* \star *}$ & & $2.21^{\star \star *}$ & \\
\hline & 0.41 & 0.43 & & & 0.49 & & 0.38 & & 0.41 & \\
\hline \multirow[t]{2}{*}{ Hot_IR } & $0.45^{\star \star \star}$ & $0.35^{\star * \star}$ & & & & $0.30^{* \star *}$ & $0.421^{* \star *}$ & & $0.44^{\star * *}$ & \\
\hline & 0.09 & 0.06 & & & & 0.07 & 0.09 & & 0.09 & \\
\hline \multirow[t]{2}{*}{ Control } & 0.79 & & & & & & $0.75^{\star}$ & & 0.77 & \\
\hline & 0.14 & & & & & & 0.13 & & 0.13 & \\
\hline \multirow[t]{2}{*}{ Age } & 0.99 & & & & & & 1.00 & & 1.00 & \\
\hline & 0.02 & & & & & & 0.02 & & 0.02 & \\
\hline \multirow[t]{2}{*}{ Ticket } & $1.00^{*}$ & & & & & & 1.00 & & 1.00 & \\
\hline & 0.001 & & & & & & 0.00 & & 0.00 & \\
\hline \multirow[t]{2}{*}{ Time_Invest } & 1.03 & & & & & & 1.04 & & 1.03 & \\
\hline & 0.03 & & & & & & 0.03 & & 0.03 & \\
\hline \multirow[t]{3}{*}{ Constant } & $0.004^{\star * *}$ & $0.005^{\star \star \star}$ & $0.003^{* * *}$ & $0.004^{\star * *}$ & $0.004^{* * *}$ & $0.010^{\star * *}$ & $0.004^{* * *}$ & $0.003^{* * *}$ & $0.004^{* * *}$ & $0.003^{* * *}$ \\
\hline & 0.002 & 0.002 & 0.00 & 0.002 & 0.002 & 0.006 & 0.002 & 0.001 & 0.002 & 0.001 \\
\hline & & & & & & & & & & Continues \\
\hline$\overbrace{\text { OPEN ACCESS }}$ & $\underbrace{}_{B O A B}$ & Scopus ${ }^{\circ}$ & & & & & & & & BA \\
\hline
\end{tabular}




\section{Table 4 (continued)}

\begin{tabular}{|c|c|c|c|c|c|c|c|c|c|c|}
\hline \multicolumn{11}{|c|}{ Models } \\
\hline Variables & (1) & (2) & (3) & (4) & (5) & (6) & (7) & (8) & (9) & (10) \\
\hline $\begin{array}{l}\text { Number of } \\
\text { observations }\end{array}$ & 252 & 470 & 470 & 470 & 470 & 470 & 252 & 470 & 252 & 470 \\
\hline Number of failures & 138 & 181 & 181 & 181 & 181 & 181 & 138 & 181 & 138 & 181 \\
\hline wald chi-square & 146 & 312 & 71 & 90 & 97 & 109 & 152 & 74 & 130 & 80 \\
\hline $\begin{array}{l}\text { log pseudo- } \\
\text { likelihood }\end{array}$ & -176 & -287 & -360 & -201 & -197 & -193 & -175 & -360 & -175 & -35 \\
\hline
\end{tabular}

Note. $\left.\left(^{*}\right),\left(^{* \star}\right),{ }^{* * \star}\right)$ means statistically significant at $10 \%, 5 \%$ and $1 \%$ respectively. The first line of each variable contains the hazard ratio, and the second line, in parenthesis, the standard error. Hot PE is a dummy variable with value 1 if the month of the exit has a high price-earnings ratio and 0 otherwise, Hot IPO is a dummy variable with value 1 if the month of the exit has a high number of IPOs and 0 otherwise, Control is a dummy variable with value 1 if the PE fund holds more than $50 \%$ of the equity stake and 0 otherwise, Age is the age of the PE firm in the year the investment

occurred, Ticket is the size of the investment in US $\$$ and the other variables are time dummies to control the year the investment occurred. 
Favorable market conditions increase the exit rate by around 2 times. As hot market windows are relatively short and very volatile, and as the PE industry is relatively young in Brazil, fund managers aggressively exploit favorable market windows. By doing so, they are able to generate high returns and prove that Private Equity activity is profitable in the country. Our results are in accordance with the market timing and grandstanding hypotheses. They support hypotheses 1 and 2 , and they provide evidence that favorable market conditions substantially increase the chances of premature exits in Brazil.

\section{Conclusion}

Our results support the hypothesis that PE fund managers time the market in Brazil by taking advantage of high valuation cycles to sell their investments. Confirming Jenkinson and Souza (2015), our results also indicate that market conditions are much more relevant in determining exit rates than fund and deal's characteristics. We find that a hot market condition increases the probability of exiting by around 2 to 2.5 times.

We also find evidence that favorable market conditions increase the chances of quick flippers. This is especially high for moments of Brazilian real appreciation: with $20 \%$ quick flippers versus $5.6 \%$ in the case of Brazilian real depreciation. The currency risk born by PE funds that raise capital with international investors is substantial. PE funds do not hedge foreign exchange risks, and they are exposed to the Brazilian currency volatility. In order to mitigate the exposure, PE fund managers try not to concentrate all investments in the same year, spreading them around a period of three to five years (depending on the investment period) and they also benefit from windows of Brazilian currency appreciation by selling whole or partial equity stake, and by bringing companies to IPOs.

The evidence confirms the grandstand and market timing hypotheses. There is pressure to exit in favorable market conditions in order to increase fund returns and mitigate exchange risk, and this creates potential misalignment between PE funds and business owners. Business owners have to be aware of this PE incentive before accepting a fund as an investor.

Due to data limitation, we concentrated our analysis on the holding period in general, not taking the exit route into account. Although some observations had information on the exit alternative, there was lots of missing data. Besides, we were not able to include write-offs in our sample due to missing exit data. This limitation did not allow us to analyze the exit dynamic according to different routes, as in Jenkinson and Souza (2015) and Giot and Schiwnbacher (2007).

\section{References}

Artica, Insper, \& Endeavor Brasil. (2017). Empresas investidas por fundos de private equity: Lições aprendidas. Retrieved from https://www.insper.edu.br/wp-content/uploads/2018/09/Empresas-Investidas-por-PE-Brasil-white-paper.pdf

Bain \& Company. (2019). Global private equity report 2019. Retrieved from https://www.bain.com/contentassets/2792a2cbcdcf4e94acfddc077a85c5ea/bain_report_private_equity_report _2019.pdf

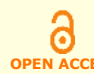

$|\mathbf{C}| \mathrm{O}|\mathrm{P}| \mathrm{E}$

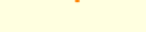


Black, B. S., Carvalho, A. G., \& Sampaio, J. O. (2014). The evolution of corporate governance in Brazil. Emerging Market Review, 20, 176-195. https://doi.org/10.1016/j.ememar.2014.04.004

Cao, J. X. (2011). IPO timing, buyout sponsors' exit strategies, and firm performance of RLBOs. Journal of Financial EB Quantitative Analysis, 46(4), 1001-1024. https://doi.org/10.1017/S0022109011000160.

Carvalho, A. G., Gallucci Netto, H., \& Sampaio, J. O. (2014). Private equity and venture capital in Brazil: An analysis of its evolution. Revista Brasileira de Finanças, 12(4), 499-515. Retrieved from http://bibliotecadigital.fgv.br/ojs/index.php/rbfin/article/view/43304

Carvalho, A. G., Gallucci-Neto, H., \& Siqueira, E. M. R. (2017). Determinants of success in venture capital investments: Evidences from Brazil. Venture Capital: An International Journal of Entrepreneurial Finance, 19(3), 147 161. https://doi.org/10.1080/13691066.2016.1247504

Foster, G., \& Morris, R. (2015). Movile's executive case: Brazil. Retrieved from http://reports.weforum.org/newmodels-for-entrepreneurship/illustrative-executive-cases/movile-executive-case-brazil/.

Gejadze, M., Giot, P., \& Schwienbacher, A. (2017). Private equity fundraising and firm specialization. The Quarterly Review of Economics and Finance, 64, 259-274. https://doi.org/10.1016/j.qref.2016.06.012

Gioielli, S. P. O., Carvalho, A. G. de, \& Sampaio, J. O. (2013). Venture capital and earnings management in IPOs. Brazilian Business Review, 10(4), 30-64. http://dx.doi.org/10.15728/bbr.2013.10.4.2

Giot, P., \& Schwienbacher, A. (2007). IPOs, trade sales and liquidations: Modelling venture capital exits using survival analysis. Journal of Banking and Finance, 31(3), 679-702. https://doi.org/10.1016/j.jbankfin.2006.06.010

Gompers, P. A. (1996). Grandstanding in the venture capital industry. Journal of Financial Economics, 42(1), 133-153. https://doi.org/10.1016/0304-405X(96)00874-4

Greene, W. H. (2000). Econometric analysis. New Jersey, NJ: Prentice Hall.

Helman, T., \& Puri, M. (2002). Venture capital and the professionalization of start-up firms: Empirical evidence. Journal of Finance, 57(1), 169-197. https://doi.org/10.1111/1540-6261.00419

Jenkinson, T., \& Sousa, M. (2015). What determines the exit decision for leveraged buyouts? Journal of Banking $\mathcal{E}$ Finance, 59, 399-408. https://doi.org/10.1016/j.jbankfin.2015.06.007

Johan, S., \& Zhang, M. (2016). Private equity exits in emerging markets. Emerging Markets Review, 29, 133-153. https://doi.org/10.1016/j.ememar.2016.08.016

Kalbfleisch, J. D., \& Prentice, R. L. (2002). The statistical analysis of failure time data (2nd ed.). New York, NY: Wiley.

Kaplan, S. N., Martel, F., \& Stromberg, P. (2007). How do legal differences and experience affect financial contracts? Journal of Financial Intermediation, 16(3), 273-311. https://doi.org/10.1016/j.jfi.2007.03.005

Kaplan, S. N., \& Schoar, A. (2005). Private equity performance: Returns, persistence, and capital flows. The Journal of Finance, 60(4), 1791-1823. https://doi.org/10.1111/j.1540-6261.2005.00780.x

Kiefer, N. M. (1988). Economic duration data and hazard functions. Journal of Economic Literature, 26(2), 646-679.

KPMG, \& ABVCAP. (2018). Consolidação de dados da indústria de Private Equity e Venture Capital no Brasil. Retrieved from https://www.abvcap.com.br/Download/Estudos/3233.pdf

Latini, E. T., Fontes-Filho, J. R., \& Chambers, E. L. (2014). Private equity and corporate governance: Managing Brazilian SMEs. Corporate Governance, 14(2), 220-237. https://doi.org/10,1108/CG-02-2013-0017

Lerner, J., Leamon, A., \& Hardymon, F. (2012). Private equity, venture capital and the financing of entrepreneurship. New York, NY: Willey.

Ljungqvist, A., \& Richardson, M. P. (2003). The cash flow, return and risk characteristics of private equity [NBER Working Papers $n^{\circ}$ 9454]. National Bureau of Economic Research, Cambridge, MA, USA.

Mariz, F. A. R., \& Savoia, J. R. F. (2005). Private equity in Brazil: A comparative perspective. The Journal of Private Equity, 9(1), 74-87. https://doi.org/10.3905/jpe.2005.605373

Masulis, R. W., \& Nataha, R. (2009). Venture capital conflicts of interest: Evidences from acquisitions of venture backed firms. Journal of Quantitative Analysis, 46(2), 395-430. https://doi.org/10.1017/S0022109010000827

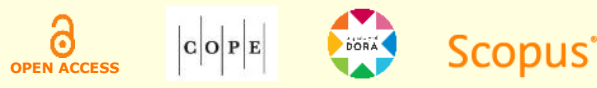


Masulis, R. W., \& Thomas, R. S. (2009). Does private equity create wealth? The effects of private equity and derivatives on corporate governance. University of Chicago Law Review, 76, 219-260. Retrieved from http://lawreview.uchicago.edu/sites/lawreview.uchicago.edu/files/76_1_Masulis_Thomas.pdf

Metrick, A., \& Yasuda, A. (2010). The economics of private equity funds. Review of Financial Studies, 23(6), 2303. 2341. https:// doi.org/10.1093/rfs/hhq020

Minardi, A. M. A. F., Ferrari, G. L., \& Tavares, P. C. (2013). Performances of Brazilian IPOs backed by private equity. Journal of Business Research, 66(1), 448-455. https://doi.org/10.1016/j.jbusres.2012.04.012

Minardi, A. M. A. F., Kanitz, R. V., Bassani, R. H. (2014). Private equity and venture capital industry performance in Brazil: 1990 - 2013. The Journal of Private Equity, 17(4), 48-58. https://doi.org/10.3905/jpe.2014.17.4.048

Minardi, A. M. A. F., Kanitz, R. V., Bassani, R. H., \& Schittkowski, P. (2017). Currency impact in Brazilian PE/VC deals. The Journal of Private Equity, 20(3), 45-51. https://doi.org/10.3905/jpe.2017.20.3.045

Muscarella, C., \& Vetsuypens, M. (1990). Efficiency and organizational structure: A study of reverse LBOs. Journal of Finance, 45(5), 1389-1413. https://doi.org/10.1111/j.1540-6261.1990.tb03720.x

Ramalho, C., Furtado, C., \& Lara, R. (2011). A indústria de private equity e venture capital no Brasil: $2^{\circ}$ censo brasileiro. Retrieved from http://bibliotecadigital.fgv.br/dspace/bitstream/handle/10438/8419/ Private_Equity_e_Venture_Censo.pdf?sequence $=1 \&$ isAllowed $=\mathrm{y}$

Ribeiro, L. L., \& Carvalho, A. G. (2008). Private equity and venture capital in emerging economy: Evidence from Brazil. Venture Capital: An International Journal of Entrepreneurial Finance, 10(2), 111-126. https://doi.org/10.1080/13691060801946121

Rossi, L. E. M., \& Martenlanc, R. (2013). An analysis of the management practices of Brazilian private equity firms and their impact on company performance. Venture Capital: An International Journal of Entrepreneurial Finance, 15(2), 151-172. https://doi.org/10.1080/13691066.2013.802165

Stromberg, P. (2008). The new demography of private equity [Working paper]. Swedish Institute for Financial Research, Stockholm, Sweden.

Valkama, P., Maula, M., Nikoskelainen, E., \& Wright, M. (2013). Drivers of holding period firm-level returns in private equity-backed buyouts. Journal of Banking $\mathcal{E} \quad$ Finance, 37(7), 2378-2391. https://doi.org/10.1016/j.jbankfin.2013.01.042

Wright, M., Amess, K., Weir, C., \& Girma, S. (2009). Private equity and corporate governance: Retrospect and prospect. Corporate Governance: An International Review, 17(3), 353-375. https://doi.org/10.1111/j.14678683.2009.00744.x

Zarutskie, R. (2010). The role of top management team human capital in venture capital markets: Evidence from first-time funds. Joumal of Business Venturing, 25(1), 155-172. https://doi.org/10.1016/j.jbusvent.2008.05.008

Zeisberger, C., Prahl, M., \& White, B. (2017). Mastering private equity: Transformation via venture capital, minority investments $\mathbb{E}$ buyouts. Hoboken, NJ: Wil.

\section{Author contributions}

$1^{\text {st }}$ author: conceptualization (lead), data curation (lead), formal analysis (lead), investigation (lead), methodology (lead), validation (lead), writing-original draft (lead), writing-review and editing (lead).

$2^{\text {nd }}$ author: formal analysis (supporting), investigation (supporting), methodology (supporting), project administration (supporting), validation (supporting), writing-original draft (supporting), writing-review and editing (supporting).

$3^{\text {rd }}$ author: conceptualization (supporting), data curation (supporting), formal analysis (supporting), investigation (supporting), writing-original draft (supporting), writing-review and editing (supporting).

$4^{\text {th }}$ author: formal analysis (supporting), methodology (supporting), writing-original draft (supporting), writing-review and editing (supporting). 


\section{Authors}

Andréa Maria Accioly Fonseca Minardi

Insper

Rua Quatá, 300, 04546-042, São Paulo, SP, Brazil

minardi@insper.edu.br

(iD) http://orcid.org/0000-0003-3528-910X

\section{Adriana Bruscato Bortoluzzo}

Insper

Rua Quatá, 300, 04546-042, São Paulo, SP, Brazil

AdrianaB@insper.edu.br

(iD) https://orcid.org/0000-0003-2872-031X

Piero Rosatelli

Insper

Rua Quatá, 300, 04546-042, São Paulo, SP, Brazil

piero@oriacapital.com.br

(iD) https://orcid.org/0000-0001-7406-3045

Priscila Fernandes Ribeiro

Insper

Rua Quatá, 300, 04546-042, São Paulo, SP, Brazil

priscilafr1@insper.edu.br

(iD) https://orcid.org/0000-0002-3482-1734 